\section{Questión}

Periodismo / Comunicación ISSN 1669-6581
- Av. $44 \mathrm{~N}^{\circ} 676,1^{\circ}$ piso

CP 1900 - La Plata - Argentina

(4) www.perio.unlp.edu.ar/question

El Covid-19 en clave guaraní

Rino Giret Britez

https://doi.org/10.24215/16696581e387

\title{
El Covid-19 en clave guaraní
}

\section{The Covid-19 in Guarani key}

Rino Giret Britez rinogiret@hotmail.com

\section{Palabras clave}

Pandemia - Paraguay - Medios - Trabajo

\section{Keywords}

Pandemic - Paraguay - Media - Work

El 7 de marzo pasado, el Covid-19 irrumpió abruptamente en la agenda de los medios de comunicación en Paraguay, con el anuncio del Ministerio de Salud Pública de que se había detectado y confirmado el primer caso de coronavirus en el país. La tranquilidad de ese sábado se vió alterada por un tuit del ministro de Salud, Julio Mazzoleni, quien informó del primer caso y luego en conferencia prensa brindó los detalles: se trataba de un paraguayo que provino de Ecuador.

Cuatro días después, el Gobierno del presidente Mario Abdo Benítez implementó la cuarentena que arrancó el 11 con la suspensión por 15 días, inicialmente, de las clases en todos los centros educativos, sean públicos o privados. Paraguay se convertía así en el primer país del Cono Sur en someter a su población a cuarentena, mientras sus principales vecinos, Brasil y Argentina, se mostraban todavía indiferentes. La medida sorprendió y fue percibida al principio como drástica, pero con el devenir de los acontecimientos fue considerada como un acierto de la autoridad sanitaria.

A partir de allí se sucedieron las conferencias de prensa en una seguidilla de anuncios que incluyeron el aislamiento social obligatorio desde el lunes 16 , con la consecuente paralización de la economía. 
El virus de la lejana Wuhan en China y del que todos habían escuchado en las noticias internacionales había aterrizado de golpe, paralizando la vida del país y dando inicio a la pesadilla colectiva del encierro, y convirtiendo en realidad lo que la ficción mostraba en las películas.

El Covid-19 acaparó la atención de la opinión pública y el virus contagió por completo la agenda mediática. La mayoría de los medios impusieron el teletrabajo, y las entrevistas y reuniones de prensa pasaron a la realidad virtual.

\section{La crisis económica}

Para combatir la pandemia y sus efectos económicos, el Gobierno puso en marcha un plan que consistió en contraer deudas por 1.600 millones de dólares para invertir en equipamiento sanitario y en programas de subsidios a trabajadores formales e informales que dejaron de percibir ingresos por la paralización económica. Más de 7.000 empresas suspendieron temporalmente los contratos de trabajo, lo que afectó a casi cien mil empleos formales.

En un país donde gran parte de su economía está sumergida en la informalidad, los verdaderos efectos de la pandemia en el empleo son inconmensurables, pero igualmente devastadores.

La prolongación de la cuarentena obligatoria con aislamiento social hizo que la contracara de la pandemia sea una crisis económica sin precedentes, que puso a miles de empresas al borde de la quiebra y a cientos de miles de personas sin empleo.

El Covid-19 también puso de manifiesto de manera dramática la mísera inversión que el Estado destinó siempre a la salud pública, que ante la emergencia sanitaria mostró sus números vergonzantes: menos de 400 unidades de terapia intensiva en todo el país para una población que supera los 7 millones de habitantes. Ante esas cifras, la propagación del virus se presentaba como una amenaza que podía hacer colapsar el endeble sistema de salud y arrojar un saldo aterrador de víctimas fatales.

Los medios de comunicación y las redes sociales jugaron un papel fundamental en la campaña por lograr aplanar la curva de contagio y el "quedate en casa" se volvió una frase que interpelaba y obligaba al comportamiento social.

Pero la pandemia también le devolvió al Estado el rol preponderante en una sociedad que siempre adoleció de la ausencia del mismo en diversas áreas de la vida nacional. En una situación límite como la que impuso el Covid-19, el rol del Estado para proteger, sanar, alimentar y contener cobró una dimensión inusitada y vital. En la agenda política se instaló la necesidad 
de dialogar sobre una reforma del Estado que permita realizar cambios estructurales para superar las viejas deficiencias que quedaron al desnudo en esta coyuntura. Aún así, existe incredulidad acerca de que prospere una reforma real.

La campaña sanitaria del Gobierno logró exhibir resultados favorables en estos dos meses de cuarentena: se mantuvo bajo control el nivel de contagio en el país y la capacidad de realizar los test para detectar el virus aumentó de 30 , en los primeros días, a 800 , como se registra en los días recientes. Hasta el 14 de mayo, la cantidad de infectados ascendía a 754, los fallecidos sumaban 11 y eran 184 las personas que lograron recuperarse del virus.

Pero la buena performance alcanzada en la campaña sanitaria se vio empañada por casos de corrupción que se detectaron en las compras públicas de insumos y equipos médicos para hacer frente a los efectos de la pandemia. Los escándalos estallaron a través de la prensa y no tardaron en aparecer renuncias obligadas de directores de entes públicos, con el consecuente desprestigio político del Gobierno.

\section{Despidos en la prensa}

Los coletazos de la crisis económica derivada de la pandemia golpearon con fuerza al periodismo paraguayo. El lunes 4 de mayo quedará registrado como el "lunes negro" de la prensa debido a que ese día se dieron despidos masivos en varios medios comunicación; casi 100 periodistas y trabajadores de prensa fueron desvinculados como parte de una decisión concertada de varias empresas del ramo. A esto se sumó el cierre de algunos medios, debido a la fuerte caída de la inversión publicitaria.

Si bien la circulación comunitaria del virus es baja en Paraguay, la frontera con el Brasil se convirtió en la principal amenaza para la salud pública, debido a que muchos paraguayos que fueron a trabajar a ese país vuelven por la crisis económica, y al ingresar son confinados a albergues dispuestos por el Gobierno. Desde los primeros días de mayo el índice de infectados registró bruscos aumentos con los test practicados en esos albergues a los repatriados.

El retorno masivo de paraguayos de otros países como Argentina también marca un rostro diferente de la pandemia. Ante la falta albergues, el Gobierno puso en marcha un plan piloto que habilitó 11 hoteles para recepcionar a los repatriados a fin de cumplir la cuarentena de 14 días. El 4 de mayo se implementó la llamada "cuarentena inteligente", con el objetivo de reactivar la economía por etapas. Se trata de un plan que consta de 4 fases y cuya aplicación depende de 
cómo se vaya comportando la curva de contagio. La autoridad sanitaria dejó en claro que en caso de que esa curva se descontrole se restringirán nuevamente las actividades. La primera fase benefició a la industria, servicios y obras civiles; la segunda se inicia el 25 y abarcará al comercio, uno de los sectores más golpeados.

Aunque persiste incertidumbre sobre el futuro, la única certeza que todos comparten es que habrá que acostumbrarse al "modo covid de vivir", por lo menos para lo que resta de este inolvidable 2020. 